acted on the view that such common 'free' carpels as follicles and achenes exemplified their units and demonstrated some of the ways in which still older organs had been transformed, reduced in numbers, aborted or suppressed, and gradually rearranged on some uniform specific plan. Despite their union in pistils, they still showed, per species, a single carpelform. Nevertheless, although there was constant reference to facts of development and histology and to all manner of final forms of pistil, opinion on gynoecial construction had come no nearer to harmony than it had been from the days of Braun and Eichler to those of Kerner and Klein.

The bearing of Miss Saunders' views may be made plain through a few points of past interest. Thus, while some believed that facts of development were of great value in the interpretation of all organs, others considered that adult form and structure gave the surest guide. There was also a mode of thought which gave prominence to vascular tissue not only as a major index to the status of an organ but also as a sign of its modification, or as a pointer to its prior development in a given position. There was a common language explaining the arrangement of vascular strands, their modes of branching, the remarkable conservatism of a vascular system, and the usefulness of 'vestigial' strands in tracing the old sites of arrested organs. Further, some believed that a leaf may be truly terminal since, as they said, a legume is a unit carpellary leaf and is fully distal. Others rejected this view and regarded a legume as the sole and displaced survival of a lateral group of 'leaves'. They read all 'syncarpous' gynœecia according to their notions of numbers and arrangements of lateral leaves, of those which had been suppressed, and of those which were now displaced.

Miss Saunders entered this field convinced that there could be no agreement on a 'fundamental ground-plan' for any pistillate family so long as the concept of a monomorphic carpel was the starting point in phyletic discussion. She pointed, in particular, to the unsettled controversies over pistil construction in the Cruciferæ and other affinities, to the seemingly insoluble problem of the 'commissural' stigma, to the varying interpretations of obdiplostemony, to the wide range of ovule placentation still unexplained, and to the difficulties facing all monomorphists when they turned to families with 'supernumerary' styles. For these and all related. matters she claimed the need of a new approach.

Her first proposal was as startling as it was simple, in that it visualized carpel dimorphism as shown to-day by many flowering groups. The heart of her view was that even a single pistil comprises united leaves; some with the form and the function of ovule-bearing organs, others of distinctive form and the function of which is stigmatic. Through this she sought early to rationalize cruciferous and other gynoecia and to explain the presence of commissural stigmas. As did others who opposed her plan for an extension of a 'leafy' view of carpels, she relied largely on the form and vasculation of mature organs. She came to identify and arrange her united carpel forms according to her estimate of branched or unbranched vascular strands, the positions of ovules upon ovarial walls, the arrangement of stigmas, and the older conception of the cyclic construction of a flower. It was inevitable that she should reject the conception of a terminal leaf once she had decided to interpret a distal legume as a union-product of distinctive carpel forms. Also it was natural that, with strands as a major instrument in the identification of unit organs, she extended her dimorphic view into a doctrine of carpel polymorphism. One cannot attempt to outline the many directions in which she sought later to apply her theory and to settle once and for all the fundamental ground-plans of floral construction on which she had set her heart. But her final volumes are in themselves a glowing testimony to the breadth of her inquiries, to her courage, and to the great array of facts which she disclosed.

It may be long before there is common agreement as to the chief objective of floral study and the valuation of the evidence on which Miss Saunders relied. But it may truly be said that few of her contemporaries in formal morphology stirred imagination more deeply than she, or did so much to stimulate inquiry.

J. McL. Thompson.

\section{Mr. H. E. Potts}

THE very narrow but nevertheless important field of patent law and practice has lost a great mind by the death of Mr. H. E. Potts on July 4. He was an earnest and original contributor to the literature of patent law. Early in his career as a chartered patent agent, he was struck by the fact that, in the drafting of patent specifications and claims, a patent agent had to call upon powers of analysis and then subsequent synthesis, and that this logical process should have some analogy in mathematics. His first contribution on "An Application of Mathematics to Law" was indeed to Nature of April 24, 1913 (p. 187), and this has been followed over the years by a development of the idea there lightly touched upon.

Although possibly never hitherto positively appreciated, it is nevertheless a fact that a patent granted upon an invention when tested by the High Courts of Great Britain is either 'wholly bad' or 'wholly good'. It is believed that Mr. Potts was the first to point out that there should be some method of assessing validity quantitatively, as well as qualitatively; and recently he put forward a number of suggestions in regard to the appreciation of monopolies of invention as granted by the Crown on a graduated basis, as distinct from the 'all good' or 'all bad', developing this proposition side by side with its mathematical exposition and following accepted theories of modern philosophy.

Of many valuable publications, perhaps Potts' best known is his book "Patents and Chemical Research", which has become a standard work in the literature on patents.

WE regret to announce the following deaths:

Mr. A. D. E. Elmer, the distinguished plant collector and author of many papers on the botany of the Philippines, in July 1942.

Dr. Frank Blair Hanson, associate director for the natural sciences at the Rockefeller Foundation, formerly professor of zoology at Washington University, St. Louis, on July 21, aged fifty-nine.

Dr. Gustave M. Meyer, associate in biochemistry during 1913-41 at the Rockefeller Institute for Medical Research, known for his work on carbohydrates and tissue chemistry, on May 9, aged sixtynine years.

The Ven. Lonsdale Ragg, founder and editor of the Tree Lover, and known for his drawings of trees, on July 31, aged seventy-eight. 